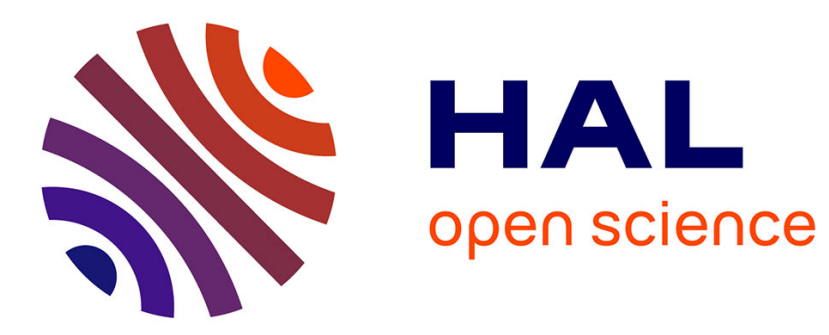

\title{
Number of episodes of reduced fetal movement at term: methodological considerations
}

Enora Laas, Stéphanie Friszer, Gilles Kayem

\section{To cite this version:}

Enora Laas, Stéphanie Friszer, Gilles Kayem. Number of episodes of reduced fetal movement at term: methodological considerations. American Journal of Obstetrics and Gynecology, 2016, 10.1016/j.ajog.2016.04.015 . hal-01304887

\section{HAL Id: hal-01304887 \\ https://hal.sorbonne-universite.fr/hal-01304887}

Submitted on 20 Apr 2016

HAL is a multi-disciplinary open access archive for the deposit and dissemination of scientific research documents, whether they are published or not. The documents may come from teaching and research institutions in France or abroad, or from public or private research centers.
L'archive ouverte pluridisciplinaire HAL, est destinée au dépôt et à la diffusion de documents scientifiques de niveau recherche, publiés ou non, émanant des établissements d'enseignement et de recherche français ou étrangers, des laboratoires publics ou privés. 
Number of episodes of reduced fetal movement at term: methodological considerations

Enora LAAS ${ }^{1}$, MD, Stéphanie FRISZER ${ }^{1}$, MD, Gilles KAYEM ${ }^{1,2}$, MD, PHD

${ }^{1}$ Department of Obstetrics and Gynecology, Trousseau Hospital, APHP, Université Pierre et Marie Curie, Paris, France

${ }^{2}$ Inserm UMR 1153, Obstetrical, Perinatal and Pediatric Epidemiology Research Team (EPOPé), Center for Epidemiology and Statistics Sorbonne Paris Cité, DHU Risks in pregnancy, Paris Descartes University, Paris France

The authors report no conflict of interest and any financial disclosure.

Corresponding author:

Enora LAAS

Department of Obstetrics and Gynecology, Trousseau Hospital

26 avenue Arnold Netter 75012 Paris, France

0171735125

Enora.laas@aphp.fr

Word count 336 
To the Editors:

We read with great interest the paper by Scala et al. who assessed the value of reduced fetal movements (RFM), showing that repeated RFM at term were strongly associated with smallfor-gestational-age (SGA) fetuses and infants.(1) Moreover, they found that RFM were more likely to occur in women with high second trimester uterine artery (UtA) Doppler resistance indices. This conclusion was based on a logistic regression analysis.

These are very interesting findings with important clinical implication, since SGA fetuses or placental dysfunction should be suspected in case of RFM, and managed as such. This article addresses a relevant question about the predictive value of one vs. repeated RFM, which is a frequent indication for emergency consultation.

However, from our point of view, some methodological concerns should be answered since they may lead to erroneous results. First, the quantitative variables (maternal age, body mass index, PAPP-A, mean UtA-Pulsatility Index (PI)) were entered in the model as quantitative predictors. This relies on the existence of a linear relation between the predictor and the outcome which is not assessed in the methods section. For example, it is not obvious that the relation between the fetal weight and the maternal age is linear(2). Moreover, the relevance of using the linear mean UtA-PI is questionable, as most of studies use the 90e percentile as predictor of adverse fetal outcome $(3,4)$. Caution should be taken regarding this point since it could lead to a misinterpretation of the results.

Second, ethnicity seems to have the "other" class as reference $(\mathrm{OR}=1)$ in the logistic regression. In table 2 , "other" includes only $0.7 \%$ of the whole population. The "Caucasian" class would have been more relevant as a reference. 
Finally, a short sentence above the table explains that "values are adjusted for other confounding variable (maternal age, BMI, ethnicity). We wonder how and why were these three factors chosen? Were they known as confounding factors for RFM and SGA?

Although these results seem promising, more details regarding the statistical method would improve the clinical relevance of the study.

\section{References}

1. Scala C, Bhide A, Familiari A, et al. Number of episodes of reduced fetal movement at term: association with adverse perinatal outcome. Am J Obstet Gynecol 2015;213:678.e1-6.

2. Watanabe H, Inoue K, Doi M, Matsumoto M, Ogasawara K, Fukuoka H, et al. Risk factors for term small for gestational age infants in women with low prepregnancy body mass index. J Obstet Gynaecol Res. 2010 Jun;36(3):506-12.

3. Yu CKH, Khouri O, Onwudiwe N, Spiliopoulos Y, Nicolaides KH, Fetal Medicine Foundation Second-Trimester Screening Group. Prediction of pre-eclampsia by uterine artery Doppler imaging: relationship to gestational age at delivery and small-for-gestational age. Ultrasound Obstet Gynecol Off J Int Soc Ultrasound Obstet Gynecol. 2008 Mar;31(3):310-3.

4. Plasencia W, Maiz N, Poon L, Yu C, Nicolaides KH. Uterine artery Doppler at $11+0$ to $13+$ 6 weeks and $21+0$ to $24+6$ weeks in the prediction of pre-eclampsia. Ultrasound Obstet Gynecol Off J Int Soc Ultrasound Obstet Gynecol. 2008 Aug;32(2):138-46. 